\title{
1199: Of Fiction and Finance
}

Daniel Defoe and the Bank of England: The Dark Arts of Projectors by Valerie Hamilton \& Martin Parker. Zero Books, 2016, ISBN 9781782799528. Pages: 189. £11.99 (pbk)

In this book Hamilton and Parker compare 'the emergence of an early English novel by Daniel Defoe, Moll Flanders (1722), and an early English corporation, the Bank of England (1694)' (p.1). In doing so, they introduce the reader to a multitude of interesting reflections on organization, fiction and projects/projectors (entrepreneurs in $21^{\text {st }}$ century parlance). Their endeavours reminded this particular reader very much of Richard Powers' Gain: A Novel (2000), which tells the story of the Clare corporation from its humble entrepreneurial beginnings in 1830 s America to late $20^{\text {th }}$ century multinational behemoth. In a reflective essay on that novel, Powers (2005) considers both the corporation and the novel to be 'an artificial being, invisible, intangible and existing only in contemplation of synthetic invention' (p.618) and suggests that 'there is no grasping where we are, no understanding of either part or whole, no representation of who we or our inventions have become, except as functions of one another' (p.617). Hamilton and Parker would no doubt subscribe to Powers' view; indeed they repeat throughout the book their central proposition that 'the novel and the organization share fundamental characteristics... they work in the same way' (p.1). But do the novel and the organization always 'operate in similar ways' (p.8; also p.16)? Is it really the case that 'the Bank employs the same kind of deceit as the novel and uses exactly the same techniques' (p.45)? It is to the great credit of Hamilton and Parker that the texture of their book is so rich that I very much enjoyed my reading experience, whilst disagreeing with their central premise. This was facilitated by the fact that the authors are confident and adroit enough to acknowledge and play with the limits of authorial control, perhaps most explicitly so in the final pages where they suggest that 'the relationship [with the reader] is in some ways a bid for a sort of freedom on all our parts' (p.166) and they conclude the book on a very open note: 'Hopefully this one has been a good tale, even if the tale is not under our control, Or Defoe's, or Paterson's or Moll's. Or yours, gentle reader' (p.167).

The proposition that this perhaps-not-quite-gentle reader does not buy is that the novel and the organization employ 'the same kind of deceit' ( $p .45)$. Of course it has now become a commonplace that the fictive is not confined to the literary text but I have argued elsewhere (De Cock and Land, 2006), based on a reading of the work of Wolfgang Iser (1993), that fictionality plays a different role in the novel and the organization, and this difference is fundamental for the novel and the organization to 'work'. I follow the authors to the point when they suggest that 'Moll Flanders does not exist, she is made-up by someone who knew what they were doing' (p.41), but it certainly does not follow that 'she is a lie' as they suggest in the very next sentence. Defoe may well have described storytelling 'as a sort of Lying' but we should resist its 'dismissal as mere deception' (Iser, 1993: xi). For Iser there are two distinct process that are set in motion by the act of fictionalizing: reproduced reality is made to point to a 'reality' beyond itself as specific elements are being dislocated and transposed into the text, while it provides the imaginary with a determinacy that it would not otherwise possess (or in Hamilton 
and Parker's words: 'something inert or imaginary that comes to life, which becomes autonomous' (p.122)). What sets literary texts apart is very much the disclosure of their own fictionality and, as Iser (1993) argues, 'when a fiction signals its own fictionality, it necessitates an attitude different from that adopted toward fictions that hide their fictionality' (p.12). The literary text - and Moll Flanders is no exception - contains a range of signals to denote that it is fictive. The signals become significant through particular historically varying conventions shared by author and public, the most durable ones being the literature genres. Sometimes such a signal can be a simple subtitle on the cover as in 'Gain: A Novel'. In the case of Moll Flanders the clue is to be found on the title page which Parker and Hamilton reproduce on p.42: 'The Fortunes and Misfortunes of the Famous Moll Flanders... written from her own MEMORANDUMS'. 'Would all [Defoe's] readers understand the level of his deceit?' they ask. Perhaps the question should be slightly rephrased as: do his readers recognize the contractual sign offered here? Parker and Hamilton answer this question further on in the book when they reveal: 'This was to become a convention of the early English novel: an account would be found of a life, adventure, journey... which would then be published for the world to see' (p.98). So the title page discloses the text of Moll Flanders as fictive to an $18^{\text {th }}$ century audience just as decisively as the use of 'A Novel' on the cover page of Gain does for a $20^{\text {th }}$ century readership. In the self-disclosure of its fictionality, an important feature of the fictional text comes to the fore: it turns the whole of the world organized in the text into an 'as-if' construction. Iser (1993: 16) elaborates: '...the 'as-if' employs the represented world to stimulate affective reactions in the reader. Attitudes will be produced through which the represented world will be surpassed, while at the same time the 'impossible' or 'unreal' will take on a conceivable contour'.

Iser (1993: 12) also sees fictions 'play vital roles in the activities of cognition and behaviour, as in the founding of institutions...' but here the strategic deception is about upholding the pretence and the entities brought into being must conceal their fictional origins if they are to persist in time. In contrast to the novel, where the organization is concerned 'we agree to the contract that denies its fictionality' (p.155). Hamilton and Parker (p.47) explore how the idea of the Bank of England had to be projected, given some kind of reality before people could believe in it and then invest: 'The Governor and Company are not a Governor and Company unless the Bank exists and the Bank does not exist unless the Governor and Company exist' (p.51). We thus 'must behave as if the organization existed in order for the organization to exist, and the more robust the belief, the more stable the organization' (p.100). As they argue in a later chapter, the impression is given that the Bank has always been there, and that no-one can be reliably credited with its beginnings: 'this inevitability is illusory but part of the being of the Bank, part of how it must function' (p111). Early instabilities and indiscretions have to be forgotten and disguised. Our authors also suggest that 'a sort of projected spectral reality' is required to make the organization keep its coherence when the physical manifestations of the organization change as people move on or die and stone crumbles - a thought captured in Joseph Gandy's famous painting of the Bank of England in ruins'. So yes, both the Bank and Moll Flanders are premised on fictions, but that fiction functions in different ways in these respective cases. It is thanks to the authors' meticulous research that this reviewer could so easily find material in the pages of their 
book to substantiate a discordant argument to theirs. Hamilton and Parker certainly succeeded in their explicitly stated aim of wanting 'to write a book that allows a wide range of people to be able to read this book easily, and find something useful in it' (p.25).

Taking their cue from Defoe's essay on the 'Projecting Age', Hamilton and Parker explore the 'shift in the nature and operation of the imagination [that] took place during this time that fostered the novel and the Bank' (p.27) in the first of the three substantive historical chapters that form the core of their book (respectively titled 'Revolutions', 'Invisible Hands', and 'The Projectors'). They document how the Bank and Moll Flanders were part of a social, political and economic revolution that they both reflected and helped create, 'bringing a new market for investments and imaginations into existence' (p.94). They show, for example, how coffee-houses facilitated the emergence of the novel and the Bank and 'how these forms inherit the conversational possibilities of the coffee-house' (p.84), or how the Bank established the idea of a national debt, 'thereby making the entire nation into a commercial venture, held together by a bet on the future' (p.55). Their meticulous research not only explicates the shift in the nature of the imagination at the beginning of the $18^{\text {th }}$ century, but also maps a veritable 'Political Unconscious' (Jameson, 1981) of the age. As such Daniel Defoe and the Bank of England stands in dialogue with other recent books that aim to historicize and contextualize the emergence of modern finance, and the centrality of 'fiction' and 'projection' therein (Klaus, 2015; Stäheli, 2013). In the next chapter our authors swim against the tide of neo-liberal vindications of the 'Invisible Hand' and appropriate the famed 'Hand' as a measure of the radical contingency to be found in all human endeavours: 'Forces beyond the comprehension of the author shape the text, and forces beyond the comprehension of the projector shape all projects' (p.116). There is always a kind of 'accidental inevitability' (p.96) at work in literary and organizational projects. The final core chapter offers us an insight into the intertwining life histories of our two co-projectors: Patterson (founder of the Bank) and Defoe. It is a truly fascinating read, if a tad incongruous after ruminations on the 'death of the author' in the previous chapter (p.102). Hamilton and Parker outline how the term 'projector' carried far more negative connotations than the modern 'entrepeneur', and how our two projectors were 'projected as much as projecting, figures made by a projecting age' (p.130); they necessarily employ 'the dark arts' and are compared to 'a sorcerer's apprentice who is consumed by the magic that he plays with' (p.154).

In the concluding chapter the equivalences of Moll Flanders and the Bank of England as commercial enterprises, first broached in chapter 3 , are sketched out in more detail: they each must answer to the needs, demands and desires of an emerging market. In this respect, the market could be imagined to be projecting both the novel and the Bank. The focus thus shifts from interpretation and content to the mode of production at the time: 'The size and shape of Moll was clearly sculpted by the publishing process, which in turn was influenced by a publisher's estimate of what they might sell, and hence what they might earn... the text was shaped by the economics of writing... 'The Author' was only one of the elements in the process that brought the commodity to market' ( $p .77)$. 'The commercial and the cultural are not opposed, but always entwined' (p.164) Hamilton and Parker teach us, and this is a 
lesson that is as valid for our time than it was for Defoe's time; pace Richard Powers (2005: 614) who vividly refers to: 'The rhino at the table that no genteel artist likes to mention in aesthetic public, the font of enabling and impairment that we struggle so hard - and no one harder than this guilty novelist - to downplay or ignore'. Somewhat mischievously our authors write that they want to offer a tale 'that we hope seduces the reader and encourages you to invest credit in us. (Just as our publisher doubtless hopes the same, with their alchemy of sales figures, pages, and prices)' (p.166). In an equally mischievous move, and as way of 'enjoying our symptom', I would like to suggest that books perhaps should have the publisher recommended price precede their title - a little conceit that explains the title of this review.

Well, gentle reader of this review, the moment has come to wrap things up. Hopefully you found this a decent review; gentle to its authors even if it sits at a rather discordant angle to the central premise of their book. In any case, at £11.99 Daniel Defoe and the Bank of England is a steal. Please augment its sales figures!

Christian De Cock, University of Essex

\section{References}

De Cock, C., \& Land, C. (2006). Organization/Literature: Exploring the Seam. Organization Studies, 27(4), 517-535.

Iser, W. (1993). The Fictive and the Imaginary. Charting Literary Anthropology. Baltimore/ London: Johns Hopkins University Press.

Jameson, F. (1981/2002). The Political Unconscious: Narrative as a Socially Symbolic Act. London: Routledge.

Klaus, I. (2014). Forging Capitalism: Rogues, Swindlers, Frauds and the Rise of Modern Finance. New Haven: Yale University Press.

Powers, R. (2000). Gain: A Novel. London: William Heinemann.

Powers, R. (2005). An Artificial Being. In B. Latour \& P. Weibel (Eds.), Making Things Public:

Atmospheres of Democracy (pp. 614-619). Cambridge (MA): MIT Press.

Stäheli, U. (2013). Spectacular Speculation: Thrills, The Economy, and Popular Discourse (E. Savoth, Trans.). Stanford: Stanford University Press.

\footnotetext{
' John Soane, the architect of the $19^{\text {th }}$ century Bank of England building, commissioned Joseph Gandy to paint the recently built Bank as a fantastic labyrinth of broken columns, imagining how it might look hundreds of years in the future: http://www.soane.org/collections/soanes london/bankofengland/8
} 